\title{
The Values of Virtual Brand Community Engagement of Facebook Brand Page
}

\author{
${ }^{1}$ Zhang Jing, ${ }^{2}$ Heang Sotheara, ${ }^{3}$ Mom Virak \\ ${ }^{1,2}$ School of Management, Huazhong University of Science and Technology, China \\ ${ }^{3}$ College of Public Administration, Huazhong University of Science and Technology, China
}

\begin{abstract}
Findings from both virtual brand community (VBC) behaviors provided a good reference, which informs a strategic direction to boost brand performance. The results examined different motives, which were likely to promote VBC participation, and were extended to the degree of VBC engagement. Both passive and active engagement results varied across community types, yet they both created significant brand loyalty and satisfaction providing theoretical and managerial implication into branding literature. The findings from this study offered interesting attention toward the two adopted online engagement behaviors. Passive participation is partially contributed to providing marketing managers a general overview about the nature of lurkers, while active participants have the potential power to convert passive members into the active ones.
\end{abstract}

Keywords: Virtual Brand Community (VBC), Passive Behavior (PB), Active Behavior (AB), Brand Loyalty (BL), Brand Satisfaction (BS)

\section{Introduction}

${ }^{1}$ Social networking sites have introduced new business platform with a more relevant role in the business models (Flavián \& Guinalíu, 2005), extended possibility to get consumers engaged with brands (Garretson, 2008), and mapped social connections (Ho, 2014). Facebook as an example allows consumers with a high possibility to interact with brands in a more direct way by communicating with the brand page (Kabadayi \& Price, 2014). Given the significance of social media, a virtual brand community has been widely discussed. While many studies investigate brand community characteristics (Muniz \& O'guinn, 2001), Ouwersloot and Odekerken-Schröder (2008) argue that the question of what needs and wants community members to seek to fulfill from joining a community has been grossly neglected. Precisely the answers of why people acknowledge themselves implicitly or explicitly to a community have not been well addressed. The work of Casaló, Flavián, and Guinalíu (2007) discussed the benefits of joining the community, addressing that the relationship created via online community leads to the development of loyalty and trust. Members are emotionally bounded when their needs are satisfied. Therefore, it is important to provide more critical development of such relationship framework by generating benchmark in a more practical level.

The current study demonstrated that customers' commitment and behavior within brand communities vary significantly among different community types including both offline and online community, fan pages, and small group brand community (Munnukka, Karjaluoto, \& Tikkanen, 2015). The consequences of these commitments have arisen in the previous discussion. For example, engagement enhances consumer's attitudes toward the brand and purchasing intention (Duffett, 2015; T. Yang (2012)). Similarly, Shang, Chen, and Liao (2006) suggested that promoting community participation may also increase brand loyalty. Loyal and satisfied customers are more likely to engage in word-of-mouth (WoM) favorable to the firm (Chen, Papazafeiropoulou, Chen, Duan, \& Liu, 2014).

\footnotetext{
${ }^{1}$ This paper is the result of the dissertation submitted to Huazhong University of Science and Technology in partial fulfillment of requirements for the Degree of Doctor of Philosophy in Management
} 
Although the significance of brand community enhances the value of the brand in general, there are few papers (Gummerus, Liljander, Weman, \& Pihlström, 2012; Pihlstrom, 2012; Shi, Chen, \& Chow, 2016) that empirically discussed the online engagement behavior and its consequences. Importantly, few studies have emphasized the significance of online engagement although it has been empirically found to strengthens the value of brand community (Shang et al., 2006). For example, understanding why some members lurk should be grounded, while active involvement is activated by separate motives that further investigation should be made. Studies also suggested that common interests, values or desire among participants to discuss specific issues are also motives for community participation(Shang et al., 2006). Moreover, Ouwersloot and Odekerken-Schröder (2008) posted that on a more practical level, the brand community serves as a platform for exchanging experiences regarding the maintenance, repair, adoption, or even basic usage around the brand.

\section{Literature Review}

\subsection{Brand Management}

Keller (2013) asserted that branding is all about choices, and serves as both defensive and offensive marketing tool to maintain current customers and to acquire new potential clients with cost effectiveness (Sweeney \& Swait, 2008). Similarly, De Chernatony and Riley (1999) viewed brands as the combination of functional and emotional attributes symbolizing a promise of future customer satisfaction that helps build brand image, which is at the operational level during which the manifestation of specific elements of service brands should be emphasized. However, this would be achieved only with customers who have the sense of brand loyalty at least some certain level that tends to express such commitment toward a brand. Within this context, the importance of brand loyalty has become the most critical source of brand equity due to its direct and mediating role in creating brand equity (Rios \& Riquelme, 2008).

In the most recent branding management, brand equity is mostly recognized for its distinguished added values that drive consumer's attitudes toward purchasing intention. Marketing practitioners believe that higher equity of a brand will generate higher value for the firms. Similarly, building strong brand tends to produce greater customer loyalty, larger margins and reduce vulnerability resulted from competitive marketing actions or crises; offers more favorable customer response to a price increase or decrease; greater trade cooperation and support; increase marketing communication effectiveness and licensing and brand extension opportunity (Keller, 2001). Moreover, Wood (2000) offered a variety of approaches previously done and provided different meanings of brand equity as (i) the total value of a brand as a separable asset, (ii) a measurement of strength that consumers attach to brands and (iii) the description of the associations and beliefs consumers have about brands. Brand equity is found to increase customer loyalty and switching costs and possibly results in long-term benefit for firms with strong brands (Brady, Cronin, Fox, \& Roehm, 2008). Some companies, for instance, seeking for growth opportunity prefer acquiring existing brands establishing brand management as a formal component of corporate strategy (H. b. Kim, Kim, \& An, 2003). Wood (2000) indicated that brands should be managed as valuable long-term corporate assets, and brand management is achieved by having a multi-disciplinary focus anticipated that extends the effectiveness of brand communication.

Likewise, since the existence of brand equity concept in the 1980s, brand equity has provided the importance of the brand in marketing strategy, its managerial implications and research focus (Keller, 2013). Many authors consider brand equity as a relational market-based asset laying in the relationship of final users with brands (Delgado-Ballester \& MunueraAlemán, 2005). For example, one of the simple ways that predict customer's equity is the willing to pay a premium price for a brand he/she prefers. In other words, customers with higher equity not only pay a higher price but also act as the effective brand messengers by recommending or even convincing others to experience their preferred brand. Also, enhancing brand equity leads to higher margins (Delgado-Ballester \& Munuera-Alemán, 2005), and frequently is measured by loyalty, image, perceived quality, awareness with the expectation that it would generate competitive values that differentiate the brand (Parsa, Eidelou, Abdolahi, Maleki, \& Mehrabi, 2013).

\subsection{Brand Community}

A brand community is known non-geographical with rational structure and formed by individuals who voluntarily connect themselves with brands or products, and share their reasonably-strong commitment toward the brands (Flavián \& Guinalíu, 2005; Muniz \& O'guinn, 2001; Ouwersloot \& Odekerken-Schröder, 2008). Muniz and O'guinn (2001) provided critical implication that products or brands publically consumed tend to stand a better chance than those privately consumed in forming the community. 
According to Muniz and O'guinn (2001), the brand community is comprised of three core components. First, the consciousness of kind brings intrinsic connection. Members feel toward one another in the collective sense of difference from others who are not in the community. They share a common way of thoughts about things which are more than shared attitudes or perceived similarity or the sense of belonging. In this regards, the relationship among community members is strongly connected. In some circumstances, they never meet, but they somehow feel they know each other. Thompson and Sinha (2008) supported Muniz and O'guinn (2001) that members of the brand community frequently and publicly assert their allegiance to the brand and express their enthusiasm for the related products in the formation of the consciousness of kind. Second, community members, who are in ritual and tradition form, tend to share consumption experiences and maintain community culture; while members with the sense of responsibility collectively behavior and take action when the community falls in a time of threats.

Moreover, brand community produces significant consequences ranging from purchase intention to enhanced loyalty and satisfaction depending on the degree of members' engagement. Thompson and Sinha (2008) asserted two adoption behaviors from community participation. Firstly, community involvement may enhance the form of loyalty which is likely to influence future intention. Secondly, Membership and participation tend to create the sense of oppositional loyalty, forming a significant defensive tool. The firms may benefit from such behavior because members with oppositional loyalty may take an adversarial view of competing brands, reducing the likelihood of brand switch. For example, brand communities have the potential to alter members' adoption behavior by selectively exposing them to information about new products offered by competing brands as well as the preferred brand (Thompson \& Sinha, 2008). In other words, community members are likely to emphasize the merits of products from the preferred brand and focus on disparaging information about products from rival brands, meaning that they are exposed to less information about the merits of new products from competing brands because of their emphasis on the merits and uses of products from the preferred brand; and thus, the members tend to show their loyalty toward the product of their preferred brand and oppositional loyalty to products of competing brands (Thompson \& Sinha, 2008). Ouwersloot and Odekerken-Schröder (2008) classified four motives consumers might have to join a community namely (i) reassurance of quality for products with significant credence attributes, (ii) high involvement with the branded product category, (iii) opportunity for joint consumption, and (iv) the brand's symbolic function according to what extent the communities help customers to reach these objectives.

However, previous studies found that consumers belong to multiple communities (McAlexander, Schouten, \& Koenig, 2002), which lead to the consequences of overlapping membership (Thompson \& Sinha, 2008). For example in the market with a large community, the first movers realize the significant advantage in the form of higher adoption rates and shorter times to adoption among members of rival communities as well as among members of their communities (Thompson \& Sinha, 2008). Consumers who appear in such circumstances would do community identification they prefer (Lembke \& Wilson, 1998), especially those who are long-term members. Similarly, long-term members may lead to stronger social identification and influence the future behavior of their preferred brand(Thompson \& Sinha, 2008).

\section{Theoretical Framework}

\subsection{Virtual Brand Community Participation and Online Engagement}

Brand page primarily serves as the reliable reference with accurate and timely updates that could promote brand awareness and influence purchase decision (Shi et al., 2016; Thompson and Sinha (2008)). Consumers refer to a brand page to acquire relevant information although it does not always respond consumers' necessity (Utpal M. Dholakia, Bagozzi, \& Pearo, 2004; Hung \& Lin, 2015; Shi et al., 2016). Consumers could share and exchange information with an attempt that those pieces of messages could benefit the public (Bagozzi \& Dholakia, 2006; Nishimura, Waryszak, \& King, 2006). Similarly, Lin, Lin, and Li (2015) concluded fans adopt virtual community not only to disseminate company's product or information but also to use this platform as a discussion forum by posting and answering questions where relevant. Moreover, the sense of joy and pleasurable experience influence participation (Bernritter, Verlegh, \& Smit, 2016; McKenna \& Bargh, 1999) and become the intrinsic motives that extend members' limited time to browse brand page and socially interact with other members in the community after fulfilling informational needs (Utpal M. Dholakia et al., 2004; Utpal M Dholakia and Vianello (2009); Gummerus et al. (2012); Papacharissi \& Rubin, 2000). Members who are effectively attached to the brand may enjoy communicating with other like-minded users to share their personal experience or at least post in the form of expressing themselves, building self-image, and promote their beliefs (Malik, Hiekkanen, Dhir, \& Nieminen, 2016; Shang et al., 2006). 
Similarly, remuneration motivation involves people engaging in social networking sites and online brand-related activities with the expectation to gain future reward or economic incentives (Luarn, Lin, \& Chiu, 2015). Lucky draw, coupon or discount is a good reward encouraging brand community participation (Gummerus et al., 2012) and promotes engagement and drives consumers' positive attitude toward brand (Gilbert \& Jackaria, 2002). Treadaway and Smith (2012) asserted that customers tend to initiate new relationships with the brand when the economic benefit is available on the brand page. However, the previous study conducted on online game argued that economic benefit did not have a significant impact on economic benefit, given that those playing games frequently, and already spent money on those games did not search for economic incentives on the Facebook community (Gummerus et al., 2012). Moreover, social media make community members conveniently interact with each other through time and space, people closer to one another (Habibi, Laroche, \& Richard, 2014; Xu, Ryan, Prybutok, \& Wen, 2012). A Recent study (Xiang, Magnini, \& Fesenmaier, 2015) emphasized that members exchange opinion and discuss various brand-related topics which are then transformed into social practice, engagement, and trust (McAlexander et al., 2002).

However, not all members engage the community in the same way (Gummerus et al., 2012). Some engage with the community to provide support or to share their experience with the members, while some may act as lurkers by reading comments and/or evaluating the contents given by others. Moreover, Ahearne, Bhattacharya, and Gruen (2005) asserted that participation depends on the degree of community identification and varies with individuals' perception across community types.

\subsection{Engagement Consequences}

The consequences of community engagement may link to stronger brand relationship which protect the brand from unwanted behaviors (Hur, Ahn, \& Kim, 2011), resist to brand switching intention (Li, Robson, \& Coates, 2014), and increase willing to pay higher toward their preferred brand (Albert, Merunka, \& Valette-Florence, 2013; Chaudhuri \& Holbrook, 2002). However, Broady-Preston, Tedd, Kate Merry, and Simon (2012) argued that while passive members or lurkers may benefit from the community without posting, the community itself may receive no benefit or even negatively affected. The work of Nonnecke, Andrews, and Preece (2006) has given a further explanation that passive participants (lurkers) may benefit from the community, yet give less contribution to the community.

From a brand loyalty perspective, consumers with insufficient brand awareness may result in less interaction within the community, yet they still belong to the brand for various reasons (Belch \& Belch, 2003). Moreover, Duffett (2015) suggested that consumers may develop their cognitive loyalty from being unawareness of the brand's existence to the awareness knowledge of what the brand offers (awareness and knowledge from the cognitive attitude component) to a favorable affective attitude and brand preference. However, Thompson and Sinha (2008) demonstrated that the likelihood that leads to loyalty depends on the degree of engagement with the brand, meaning that the higher level of participation increases the likelihood of the sense of loyalty and oppositional loyalty. Thus, it is important to examine the relationship of passive behavior with attitudinal loyalty. Meanwhile posting and sharing on social media represents the formation of eWoM which is largely studied in brand loyalty and satisfaction domain (Shang et al., 2006). Hennig-Thurau, Gwinner, Walsh, and Gremler (2004) asserted that loyal consumers favorably relate their experience with others which is likely to influence purchase intention (Chen et al., 2014). Vice versa, lurkers may refer to the various information posted in the page to make their purchase decision (Shang et al., 2006).

Broady-Preston et al. (2012) emphasized that both active and passive participants receive similar benefits from the community, yet the only small percentage of passive participants perceive high satisfaction. Although Nonnecke et al. (2006) suggested that satisfaction of passive participants is relatively low but finding does not prompt any significant dissatisfaction encountered with the community. Previous studies suggested that customer engagement is the major antecedents of satisfaction which is widely accepted (Noyan \& Şimşek, 2014; Parola, Satta, Penco, \& Persico, 2014). However, the relationships between the two constructs are complex and overlapped. Y. H. Kim, Kim, and Wachter (2013) asserted that active participation could influence customer satisfaction, while Rajah, Marshall, and Nam (2008) demonstrated that satisfied customers are more engaged with the brands. However, the work Royo-Vela and Casamassima (2011) argued that there is no strong and clear relationship between the level of participation in virtual brand community and satisfaction although it tends to have some positive effect on general satisfaction, and very few virtual community members are highly engaged with community's activities.

RQ: Online community mediates the relationship of brand community participation on community consequences 


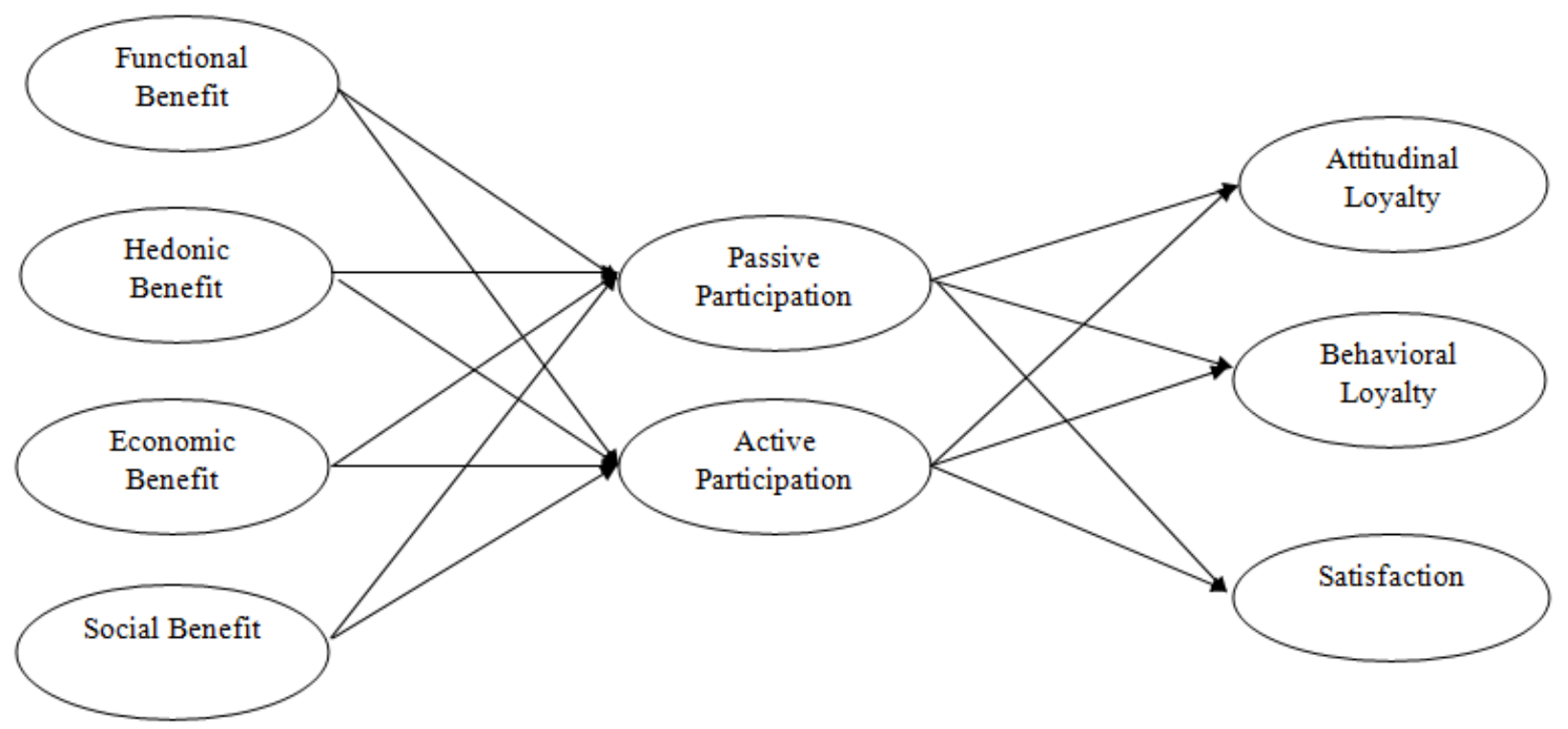

Figure 1: Research Model

\section{Research Method}

The study ultimately determines the method that evaluates all available options before making a decision. The method is adapted in the light of being the most useful for the study (Beiske, 2002). In this study, non-probability sampling is used because it is more convenient with lower cost and time constraint. This method is useful for generalizing research outcomes and determines behavioral diversity among respondents(Shabbir, 2015). Purposive sampling technique is adopted because it is useful for situations that targeted market sample could be quickly approached. Following nonprobability sampling, the suitable sample size is suggested to acquire at least 500 samples in order to get a good result for multivariate studies, where its analysis needs larger sample size for analyzing research proposition(Wimmer \& Dominick, 2013).

Both online survey and self-administered questionnaires distribution were conducted for the study. Facebook users who have joined brand pages were eligible and invited to participate. The study adopted convenience sampling method, using snowball approach. This approach was applied because it assumed homogenous population where referenced participants are informative for the study (Goodman, 1961).

\section{Result Discussion}

\subsection{Descriptive Statistics}

Both online and self-administered questionnaires were distributed, and Facebook users were invited to complete. Respondents were informed to bear in mind of any page or brand page they could think of and then were asked to rate how likely they agreed or disagreed regarding each given statement according to their personal experience with the brand page in the questionnaire. In response, the study obtained 947 returned submission. After data collection, data cleaning was applied, and 37 incomplete questionnaires accounted for $3.90 \%$ were removed from the study.

Young online users were found to dominate the study (See Table 1). This is likely that young users are more dynamic and responsive in a virtual community than considerably-old age users. The descriptive results could describe the characteristics of young consumers in the emerging market, and extend to provide grounded reference for branding managers to inform a so-called strategic direction for a prospective brand relationship. It is imperative that developing a brand takes years, and it should be started from now on with young consumers since they are more likely to contribute great potentials in enhancing future brand value. 
Table 1: Respondents' Profile

\begin{tabular}{|c|c|c|c|}
\hline Variable $(n=910)$ & & Frequency & Percentage (\%) \\
\hline \multirow{2}{*}{ Gender } & Female & 353 & 38.8 \\
\hline & Male & 557 & 61.2 \\
\hline \multirow{4}{*}{ Age (in years) } & Less than 20 & 526 & 57.8 \\
\hline & $21-30$ & 311 & 34.2 \\
\hline & $31-40$ & 63 & 6.9 \\
\hline & More than 40 & 10 & 1.1 \\
\hline \multirow{4}{*}{ Education } & High School/Bellow & 439 & 48.2 \\
\hline & Undergraduate & 346 & 38.0 \\
\hline & Postgraduate/Above & 121 & 13.3 \\
\hline & Others & 4 & 0.40 \\
\hline \multirow{6}{*}{ Occupation } & Student & 667 & 73.3 \\
\hline & Employee & 99 & 10.9 \\
\hline & Official & 115 & 12.6 \\
\hline & Business Owner & 8 & 0.9 \\
\hline & Housewife & 5 & 0.5 \\
\hline & Others & 16 & 1.8 \\
\hline \multirow{5}{*}{ Monthly Income (in USD) } & No income & 611 & 67.1 \\
\hline & $<500$ & 186 & 20.4 \\
\hline & $501-800$ & 68 & 7.5 \\
\hline & $801-1000$ & 15 & 1.6 \\
\hline & More than 1000 & 30 & 3.3 \\
\hline \multirow{4}{*}{ Daily FB Duration } & Less than 1 hour & 478 & 52.5 \\
\hline & 1-3 hours & 351 & 38.6 \\
\hline & 4-6 hours & 65 & 7.1 \\
\hline & More than 7 hours & 16 & 1.8 \\
\hline
\end{tabular}

Table 2: Pearson's Correlation

\begin{tabular}{|c|c|c|c|c|c|c|c|c|c|}
\hline & FB & HB & EB & SB & $\mathrm{PB}$ & $\mathrm{AB}$ & $\mathrm{AL}$ & $\mathrm{BL}$ & $\mathrm{BS}$ \\
\hline FB & 1 & & & & & & & & \\
\hline HB & $.332^{* *}$ & 1 & & & & & & & \\
\hline EB & $.319^{* *}$ & $.385^{* *}$ & 1 & & & & & & \\
\hline SB & $.355^{* *}$ & $.420^{* * *}$ & $.555^{\text {** }}$ & 1 & & & & & \\
\hline PB & $.446^{* *}$ & $.513^{* *}$ & $.323^{* *}$ & $.422^{* *}$ & 1 & & & & \\
\hline $\mathrm{AB}$ & $.398^{* *}$ & $.476^{* *}$ & $.449^{* *}$ & $.623^{* *}$ & $.487^{* * *}$ & 1 & & & \\
\hline $\mathrm{AL}$ & $.450^{* *}$ & $.478^{* *}$ & $.366^{* *}$ & $.539^{* *}$ & $.503^{* *}$ & $.627^{* *}$ & 1 & & \\
\hline BL & $.384^{* *}$ & $.397^{* *}$ & $.492^{* *}$ & $.512^{* *}$ & $.410^{* * *}$ & $.543^{* *}$ & $.599^{* *}$ & 1 & \\
\hline BS & $.396^{* *}$ & $.388^{* *}$ & $.374^{* *}$ & $.490^{* *}$ & $.447^{* *}$ & $.538^{* *}$ & $.599^{* *}$ & $.632^{* *}$ & 1 \\
\hline
\end{tabular}

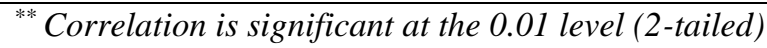

\subsection{Mediation Analysis}

The mediation is referenced following Zhao and Lynch Jr (2010) principles as follow:

1. Complementary mediation: Mediated effect ( $\mathrm{a} \times \mathrm{b})$ and direct effect (c) both exist and point in the same direction, suggesting an incomplete theoretical framework. Mediator identified consistently, but consider the likelihood of an omitted mediator in the "direct" path.

2. Competitive mediation: Mediated effect ( $\mathrm{a} \times \mathrm{b}$ ) exists, and direct effect (c) both exist and point in opposite directions, suggesting the same procedure as in complementary mediation.

3. Indirect-only mediation: Mediated effect $(\mathrm{a} x \mathrm{~b}$ ) exists, but no direct effect. Mediator identified consistent with hypothesized theoretical framework. 
4. Direct-only nonmediation: Direct effect (c) exists, but no indirect effect, suggesting a problematic theoretical framework. Consider the likelihood of an omitted mediator.

5. No-effect nonmediation: Neither direct effect nor indirect effect exists, suggesting neither direct nor indirect effects are detected. Wrong theoretical framework.

Following Hayes (2012), three main types of mediation procedures were adopted:

i. $\quad$ Estimate the relationship between independent variables of functional benefit (FB), hedonic benefit (HB), economic benefit (EB), and social benefit (SB) with mediator variables passive behavior (PB) and active behavior (AB), the so-called path (a).

ii. Estimate direct effects of independent variables and mediators on dependent variables, a so-called path (b) and (c).

iii. Estimate the indirect effects of independent variables on dependent variables through mediators, a so-called path $(\mathrm{a} \times \mathrm{b})$.

Table 3: Mediation Result with Attitudinal Loyalty

\begin{tabular}{|c|c|c|c|c|}
\hline & $\beta$ & $t$ & $p$ & Finding \\
\hline \multicolumn{5}{|l|}{ Direct effect of path (a) } \\
\hline $\mathrm{FB} \rightarrow \mathrm{PB}$ & .493 & 15.021 & .000 & Positive effect of FB on PB \\
\hline $\mathrm{HB} \rightarrow \mathrm{PB}$ & .463 & 17.993 & .000 & Positive effect of $\mathrm{HB}$ on $\mathrm{PB}$ \\
\hline $\mathrm{EB} \rightarrow \mathrm{PB}$ & .271 & 10.274 & .000 & Positive effect of EB on $\mathrm{PB}$ \\
\hline $\mathrm{SB} \rightarrow \mathrm{PB}$ & .383 & 14.012 & .000 & Positive effect of SB on PB \\
\hline $\mathrm{FB} \rightarrow \mathrm{AB}$ & .469 & 13.084 & .000 & Positive effect of $\mathrm{FB}$ on $\mathrm{AB}$ \\
\hline $\mathrm{HB} \rightarrow \mathrm{AB}$ & .459 & 16.309 & .000 & Positive effect of $\mathrm{HB}$ on $\mathrm{AB}$ \\
\hline $\mathrm{EB} \rightarrow \mathrm{AB}$ & .402 & 15.142 & .000 & Positive effect of $\mathrm{EB}$ on $\mathrm{AB}$ \\
\hline $\mathrm{SB} \rightarrow \mathrm{AB}$ & .603 & 23.980 & .000 & Positive effect of SB on $\mathrm{AB}$ \\
\hline \multicolumn{5}{|l|}{ Direct effect of path (b) } \\
\hline $\mathrm{PB} \rightarrow \mathrm{AL}$ & .500 & 17.531 & .000 & Positive effect of $\mathrm{PB}$ on $\mathrm{AL}$ \\
\hline $\mathrm{AB} \rightarrow \mathrm{AL}$ & .586 & 24.261 & .000 & Positive effect of $\mathrm{AB}$ on $\mathrm{AL}$ \\
\hline \multicolumn{5}{|l|}{ Direct effect of path (c) } \\
\hline $\mathrm{FB} \rightarrow \mathrm{AL}$ & .495 & 15.178 & .000 & Positive effect of FB on AL \\
\hline $\mathrm{HB} \rightarrow \mathrm{AL}$ & .430 & 16.415 & .000 & Positive effect of $\mathrm{HB}$ on $\mathrm{AL}$ \\
\hline $\mathrm{EB} \rightarrow \mathrm{AL}$ & .306 & 11.836 & .000 & Positive effect of EB on AL \\
\hline $\mathrm{SB} \rightarrow \mathrm{AL}$ & .479 & 18.852 & .000 & Positive effect of SB on AL \\
\hline Indirect effect of Path $(a x b)$ & $\beta$ & Remarks & & Finding \\
\hline \multicolumn{5}{|l|}{ Passive behavior as mediator } \\
\hline $\mathrm{FB} \rightarrow \mathrm{PB} \rightarrow \mathrm{AL}$ & .246 & Sig. & \multicolumn{2}{|c|}{ Indirect effect of $\mathrm{FB}$ on $\mathrm{AL}$ through $\mathrm{PB}$} \\
\hline $\mathrm{HB} \rightarrow \mathrm{PB} \rightarrow \mathrm{AL}$ & .231 & Sig. & \multicolumn{2}{|c|}{ Indirect effect of $\mathrm{HB}$ on $\mathrm{AL}$ through $\mathrm{PB}$} \\
\hline $\mathrm{EB} \rightarrow \mathrm{PB} \rightarrow \mathrm{AL}$ & .135 & Sig. & \multicolumn{2}{|c|}{ Indirect effect of EB on AL through PB } \\
\hline $\mathrm{SB} \rightarrow \mathrm{PB} \rightarrow \mathrm{AL}$ & .191 & Sig. & \multicolumn{2}{|c|}{ Indirect effect of SB on AL through PB } \\
\hline \multicolumn{5}{|l|}{ Active behavior as mediator } \\
\hline $\mathrm{FB} \rightarrow \mathrm{AB} \rightarrow \mathrm{AL}$ & .274 & Sig. & \multicolumn{2}{|c|}{ Indirect effect of $\mathrm{FB}$ on $\mathrm{AL}$ through $\mathrm{AB}$} \\
\hline $\mathrm{HB} \rightarrow \mathrm{AB} \rightarrow \mathrm{AL}$ & .268 & Sig. & \multicolumn{2}{|c|}{ Indirect effect of $\mathrm{HB}$ on $\mathrm{AL}$ through $\mathrm{AB}$} \\
\hline $\mathrm{EB} \rightarrow \mathrm{AB} \rightarrow \mathrm{AL}$ & .235 & Sig. & \multicolumn{2}{|c|}{ Indirect effect of EB on AL through $\mathrm{AB}$} \\
\hline $\mathrm{SB} \rightarrow \mathrm{AB} \rightarrow \mathrm{AL}$ & .353 & Sig. & \multicolumn{2}{|c|}{ Indirect effect of $\mathrm{SB}$ on $\mathrm{AL}$ through $\mathrm{AB}$} \\
\hline
\end{tabular}

As indicated in Table 3, the mediation test on passive and active behavior was estimated, presenting the significant results on the path (a), (b) and (c). For path (a) analysis, each separate independent variable was estimated for significance on each mediator variable. Direct effect of path (a) of hedonic benefit, functional benefit, economic benefit and social benefit presented positive significant effects on passive behavior with estimates value $(\beta=.493, p<.05),(\beta=.463, p<.05),(\beta=.272$, $\mathrm{p}<.05)$, and $(\beta=.383, \mathrm{p}<.05)$ respectively. 
Similarly, the direct effects of functional benefit were positively significant on active behavior $(\beta=.469$, $p<.05)$, while hedonic benefit showed significant direct effect $(\beta=.459, \mathrm{p}<.05)$ on active behavior. Both economic and social benefit had significant direct effects on active behavior $(\beta=.402, \mathrm{p}<.05)$ and $(\beta=.603, \mathrm{p}<.05)$ respectively.

Path (b) represented by mediator variables as the independent variable was estimated for statistically significance on attitudinal loyalty. As indicated in Table 5-13, both passive and active behavior were found to have significant direct effects on attitudinal loyalty, $(\beta=.500, \mathrm{p}<.05)$ and $(\beta=.586, \mathrm{p}<.05)$ respectively. To estimate mediation, path (c) was conducted. If path (c) was also significant, mediation effect was likely to happen to mediate the effect of independent variables (functional, hedonic, economic and social benefit) on dependent variables (attitudinal loyalty). As expected, a functional, hedonic, economic and social benefit presented significant direct effects on attitudinal loyalty $(\beta=.495, p<.05)$, $(\beta=.430, \mathrm{p}<.05),(\beta=.306, \mathrm{p}<.05)$ and $(\beta=.479, \mathrm{p}<.05)$ respectively.

The indirect effects, path ( $\mathrm{a} \times \mathrm{b}$ ) were estimated as shown in Table 3. The indirect effect of functional benefit on attitudinal loyalty through passive behavior was significantly found $(\beta=.246, p<.05)$. Similarly, a hedonic benefit presented significant indirect effect on attitudinal loyalty through passive behavior $(\beta=.231, \mathrm{p}<.05)$. While economic benefit showed significant indirect effect $(\beta=.135, \mathrm{p}<.05)$, a social benefit presented indirect effect on attitudinal loyalty $(\beta=.191$, $\mathrm{p}<.05$ ).

The indirect effect through active behavior was tested. Functional benefit presented significant indirect effect on attitudinal loyalty through active behavior $(\beta=.274, \mathrm{p}<.05)$. Additionally, the hedonic benefit was found to have an indirect effect on attitudinal loyalty through active behavior $(\beta=.268, \mathrm{p}<<.05)$. The Economic benefit had an indirect effect $(\beta=.235, \mathrm{p}<.05)$ on attitudinal loyalty through active behavior. Lastly, a social benefit presented indirect effect $(\beta=.353, \mathrm{p}<.05)$ on attitudinal loyalty.

Table 4: Mediation Result with Behavioral Loyalty

\begin{tabular}{|c|c|c|c|c|}
\hline & $\boldsymbol{\beta}$ & $t$ & $p$ & Finding \\
\hline \multicolumn{5}{|l|}{ Direct effect of path $(b)$} \\
\hline $\mathrm{PB} \rightarrow \mathrm{BL}$ & .484 & 13.561 & .000 & Direct effect of $\mathrm{PB}$ on $\mathrm{BL}$ \\
\hline $\mathrm{AB} \rightarrow \mathrm{BL}$ & .601 & 19.484 & .000 & Direct effect of $\mathrm{AB}$ on $\mathrm{BL}$ \\
\hline \multicolumn{5}{|l|}{ Direct effect of path (c) } \\
\hline $\mathrm{FB} \rightarrow \mathrm{BL}$ & .502 & 12.550 & .000 & Direct effect of FB on BL \\
\hline $\mathrm{HB} \rightarrow \mathrm{BL}$ & .423 & 13.032 & .000 & Direct effect of $\mathrm{HB}$ on $\mathrm{BL}$ \\
\hline $\mathrm{EB} \rightarrow \mathrm{BL}$ & .488 & 17.041 & .000 & Direct effect of $\mathrm{EB}$ on $\mathrm{BL}$ \\
\hline $\mathrm{SB} \rightarrow \mathrm{BL}$ & .549 & 17.982 & .000 & Direct effect of SB on BL \\
\hline Indirect effect of path $(a x b)$ & $\boldsymbol{\beta}$ & Remarks & & Finding \\
\hline \multicolumn{5}{|l|}{ Passive behavior as mediator } \\
\hline $\mathrm{FB} \rightarrow \mathrm{PB} \rightarrow \mathrm{BL}$ & .238 & Sig. & \multicolumn{2}{|c|}{ Indirect effect of FB on BL through PB } \\
\hline $\mathrm{HB} \rightarrow \mathrm{PB} \rightarrow \mathrm{BL}$ & .224 & Sig. & \multicolumn{2}{|c|}{ Indirect effect of $\mathrm{HB}$ on $\mathrm{BL}$ though $\mathrm{PB}$} \\
\hline $\mathrm{EB} \rightarrow \mathrm{PB} \rightarrow \mathrm{BL}$ & .131 & Sig. & \multicolumn{2}{|c|}{ Indirect effect of EB on BL through $\mathrm{PB}$} \\
\hline $\mathrm{SB} \rightarrow \mathrm{PB} \rightarrow \mathrm{BL}$ & .185 & Sig. & \multicolumn{2}{|c|}{ Indirect effect of SB on BL through $\mathrm{PB}$} \\
\hline \multicolumn{5}{|l|}{ Active behavior as mediator } \\
\hline $\mathrm{FB} \rightarrow \mathrm{AB} \rightarrow \mathrm{BL}$ & .281 & Sig. & \multicolumn{2}{|c|}{ Indirect effect of $\mathrm{FB}$ on $\mathrm{BL}$ through $\mathrm{AB}$} \\
\hline $\mathrm{HB} \rightarrow \mathrm{AB} \rightarrow \mathrm{BL}$ & .275 & Sig. & \multicolumn{2}{|c|}{ Indirect effect of $\mathrm{HB}$ on $\mathrm{BL}$ through $\mathrm{AB}$} \\
\hline $\mathrm{EB} \rightarrow \mathrm{AB} \rightarrow \mathrm{BL}$ & .241 & Sig. & \multicolumn{2}{|c|}{ Indirect effect of $\mathrm{EB}$ on $\mathrm{BL}$ through $\mathrm{AB}$} \\
\hline $\mathrm{SB} \rightarrow \mathrm{AB} \rightarrow \mathrm{BL}$ & .362 & Sig. & \multicolumn{2}{|c|}{ Indirect effect of $\mathrm{SB}$ on $\mathrm{BL}$ through $\mathrm{AB}$} \\
\hline
\end{tabular}

As indicated in Table 4, direct effects of the path (b) of passive and active behavior on behavioral loyalty were significant $(\beta=.484, p<.05)$ and $(\beta=.601, p<.05)$ respectively. Patch (c) was then estimated for statistically significant. The result showed significant direct effects of functional, hedonic, economic and social benefit on behavioral loyalty respectively with $(\beta=.502, p<.05),(\beta=.423, p<.05),(\beta=.488, p<.05)$ and $(\beta=.549, p<.05)$. 
The results also showed indirect effects of the path $(\mathrm{a} \times \mathrm{b})$ with passive and active behavior as mediators. Passive behavior as a mediator coordinated the effect of functional benefit $(\beta=.238, p<.05)$, hedonic benefit $(\beta=.224$, $p<.05)$, economic benefit $(\beta=.131, p<.05)$ and social benefit $(\beta=.185, p<.05)$ on behavioral loyalty. Likewise, the effect of functional benefit with behavioral loyalty was mediated by active behavior $(\beta=.281, \mathrm{p}<.05)$. The effect of hedonic benefit with behavioral loyalty was mediated by active behavior $(\beta=.275, \mathrm{p}<.05)$. Economic benefit presented mediated significant effect $(\beta=.241, \mathrm{p}<.05)$ on behavioral loyalty, while the effect of social benefit on behavioral loyalty $(\beta=.362, \mathrm{p}<.05)$ was mediated by active behavior.

As shown in Table 5, the test for significance of path (b) and (c) was estimated to examine possible mediation effects. The result showed significant effects of direct path (b). Passive behavior had a significant effect $(\beta=.486, p<.05)$ on brand satisfaction, while active behavior presented higher significant effect $(\beta=.549, \mathrm{p}<.05)$ on brand satisfaction. The direct effect of the path (c) provided significant results as expected.

Table 5: Mediation Result with Satisfaction

\begin{tabular}{|c|c|c|c|c|}
\hline & $\boldsymbol{\beta}$ & $T$ & $p$ & Finding \\
\hline \multicolumn{5}{|l|}{ Direct effect of path (b) } \\
\hline $\mathrm{PB} \rightarrow \mathrm{BS}$ & .486 & 15.042 & .000 & Direct effect of PB on BS \\
\hline $\mathrm{AB} \rightarrow \mathrm{BS}$ & .549 & 19.217 & .000 & Direct effect of $\mathrm{AB}$ on $\mathrm{BS}$ \\
\hline \multicolumn{5}{|l|}{ Direct effect of path (c) } \\
\hline $\mathrm{FB} \rightarrow \mathrm{BS}$ & .477 & 12.995 & .000 & Direct effect of FB on BS \\
\hline $\mathrm{HB} \rightarrow \mathrm{BS}$ & .382 & 12.691 & .000 & Direct effect of HB on BS \\
\hline $\mathrm{EB} \rightarrow \mathrm{BS}$ & .342 & 12.156 & .000 & Direct effect of EB on BS \\
\hline $\mathrm{SB} \rightarrow \mathrm{BS}$ & .484 & 16.920 & .000 & Direct effect of SB on BS \\
\hline Indirect effect of path $(a x b)$ & $\boldsymbol{\beta}$ & Remarks & & Finding \\
\hline \multicolumn{5}{|l|}{ Passive behavior as mediator } \\
\hline $\mathrm{FB} \rightarrow \mathrm{PB} \rightarrow \mathrm{BS}$ & .239 & Sig. & \multicolumn{2}{|c|}{ Indirect of FB on BS through $\mathrm{PB}$} \\
\hline $\mathrm{HB} \rightarrow \mathrm{PB} \rightarrow \mathrm{BS}$ & .225 & Sig. & \multicolumn{2}{|c|}{ Indirect of $\mathrm{HB}$ on $\mathrm{BS}$ through $\mathrm{PB}$} \\
\hline $\mathrm{EB} \rightarrow \mathrm{PB} \rightarrow \mathrm{BS}$ & .131 & Sig. & \multicolumn{2}{|c|}{ Indirect of EB on BS through $\mathrm{PB}$} \\
\hline $\mathrm{SB} \rightarrow \mathrm{PB} \rightarrow \mathrm{BS}$ & .186 & Sig. & \multicolumn{2}{|c|}{ Indirect of $\mathrm{SB}$ on $\mathrm{BS}$ through $\mathrm{PB}$} \\
\hline \multicolumn{5}{|l|}{ Active behavior as mediator } \\
\hline $\mathrm{FB} \rightarrow \mathrm{AB} \rightarrow \mathrm{BS}$ & .257 & Sig. & \multicolumn{2}{|c|}{ Indirect effect of $\mathrm{F} B$ on $\mathrm{BS}$ through $\mathrm{AB}$} \\
\hline $\mathrm{HB} \rightarrow \mathrm{AB} \rightarrow \mathrm{BS}$ & .251 & Sig. & \multicolumn{2}{|c|}{ Indirect effect of $\mathrm{HB}$ on $\mathrm{BS}$ through $\mathrm{AB}$} \\
\hline $\mathrm{EB} \rightarrow \mathrm{AB} \rightarrow \mathrm{BS}$ & .220 & Sig. & \multicolumn{2}{|c|}{ Indirect effect of $\mathrm{EB}$ on $\mathrm{BS}$ through $\mathrm{AB}$} \\
\hline $\mathrm{SB} \rightarrow \mathrm{AB} \rightarrow \mathrm{BS}$ & .331 & Sig. & \multicolumn{2}{|c|}{ Indirect effect of $\mathrm{SB}$ on $\mathrm{BS}$ through $\mathrm{AB}$} \\
\hline
\end{tabular}

The functional benefit had a direct effect $(\beta=.477, \mathrm{p}<.05)$ on brand satisfaction. Hedonic benefit and economic benefit presented direct effects on brand satisfaction $(\beta=.382, \mathrm{p}<.05)$ and $(\beta=.342, \mathrm{p}<.05)$ respectively. The social benefit also showed significant direct effect $(\beta=.484, \mathrm{p}<.05)$.

The mediators of passive and active behaviors in this study examined indirect effect of the path (a $\mathrm{x}$ b). First, passive behavior as the mediator was examined. The effect of functional benefit with brand satisfaction $(\beta=.239, p<.05)$ was mediated by passive behavior, while hedonic showed indirect effect $(\beta=.225, \mathrm{p}<.05)$ on brand satisfaction through passive behavior.

Similarly, economic benefit showed indirect effect $(\beta=.131, p<.05)$, while social benefit had an indirect effect $(\beta=.186$, $\mathrm{p}<.05$ ) on brand satisfaction. Second, the relationship mediated by active behavior was examined. The functional benefit had an indirect effect $(\beta=.257, \mathrm{p}<.05)$, mediated by active behavior on brand satisfaction. The hedonic benefit had indirect effect $(\beta=.257, p<.05)$ through active behavior on brand satisfaction. While economic benefit showed indirect effect $(\beta=.220, p<.05)$ on brand satisfaction, a social benefit presented indirect effect $(\beta=.331, p<.05)$. 


\section{Conclusion}

The study offered an interesting contribution toward online passive and active engagement. The result showed that passive and active behavior represented complementary mediation (Zhao \& Lynch $\mathrm{Jr}, 2010$ ), and were found to coordinate the effects between participation stimuli and engagement consequences. An omitted mediator was suggested to reconsider in relation with the theoretical model. The finding emphasized the importance of how likely passive behavior contributes to brand awareness promotion offered by the brand page.

The finding showed that although passive members demonstrated the low frequency of interaction with the community, they tend to respond to the request from members who are seeking for information. Also, passive participants browsed and/or quietly read intended information posted by the brand on their page or other members to fulfill their functional need (Xiang et al., 2015). Similarly, passive engagement may link to the possibility of being entertained within the community and increase in both satisfaction and loyalty (Mathwick, Malhotra, \& Rigdon, 2001); but the degree of these relationships varied according to community types (Gummerus et al., 2012).

However, passive engagement positively mediated the effect of economic benefit on loyalty and satisfaction arguing with the previous finding that economic needs to some extent had a positive influence; while Kang, Tang, and Fiore (2015) did not find any significant relationship of monetary incentives on community participation. Interestingly, loyalty and satisfaction were bounded with the level of social value within the community, possibly giving passive members the reason to stay engaged with brand community regardless less interaction. The explanation may be extended that some passive members serve as active members in some community types, in reflection with overlapping community membership.

Active engagement positively mediated the influence of functional benefit on both loyalty forms and brand satisfaction. Previous studies support this finding that active members with the sense of belonging usually post and share community activities (Bagozzi \& Dholakia, 2006) and in return the community receives loyalty and satisfaction benefit from such behavior (Broady-Preston et al., 2012). Similarly, active behavior mediated the relationship between hedonic and economic benefits on both loyalty forms and satisfaction.

Not surprisingly, hedonic benefit, in general, serves as the core component of virtual brand community (Pihlstrom, 2012; H.-L. Yang \& Lin, 2014; Zhang Jing, 2017), which could be explained by stronger engagement with the community (Zhang Jing, 2017) while monetary incentives basically serve as a good treatment for economic need (Lee, Ahn, \& Kim, 2008) leading to purchase intention (Chandon, Wansink, \& Laurent, 2000). Moreover, a social benefit was presented via active behavior that delivers a favorable consequence in accelerating loyalty and satisfaction. The finding extends the implication of eWoM in the virtual community (Kucukemiroglu \& Kara, 2015). While sharing and posting are the common formation of eWoM, WoM itself is the consequence of satisfaction and loyalty (Pappu \& Quester, 2016; Sotheara, Jing, \& Yat, 2016).

\subsection{Limitation and Future Direction}

The study poses certain restrictions which acquire future directions to bridge the gap in virtual brand community domains. The study primarily examines Facebook brand pages and ignores other social networking sites that contribute to generating stronger evidence and extend the generalization. The response rate is heavily biased toward young consumers putting demographic constraints. Data were collected using convenience sampling approach failing to give an equal chance to other participants. Thus, the future study may consider a more scientific approach which strongly suggested in the field of social science. The empirical result provided interesting finding related to passive behavior, yet the study did not solely aim at those targets. It is critical to understand how passive participants behave toward brand because it helps to enlarge future market segments. 


\section{Acknowledgment}

The National Natural Science Foundation of China under Grant 71272125 and 71672068 sponsor this research.

\section{References}

- Ahearne, M., Bhattacharya, C. B., \& Gruen, T. (2005). Antecedents and consequences of customer-company identification: expanding the role of relationship marketing. Journal of applied psychology, 90(3), 574, CrossRef

- $\quad$ Albert, N., Merunka, D., \& Valette-Florence, P. (2013). Brand passion: Antecedents and consequences. Journal of Business Research, 66(7), 904-909, CrossRef

- $\quad$ Bagozzi, R. P., \& Dholakia, U. M. (2006). Antecedents and purchase consequences of customer participation in small group brand communities. International Journal of Research in Marketing, 23(1), 45-61, CrossRef

- Beiske, B. (2002). Research methods. Uses and limitations of questionnaires, interviews, and case studies.

- Belch, G. E., \& Belch, M. A. (2003). Advertising and promotion: An integrated marketing communications perspective: The McGraw- Hill.

- Bernritter, S. F., Verlegh, P. W. J., \& Smit, E. G. (2016). Why Nonprofits Are Easier to Endorse on Social Media: The Roles of Warmth and Brand Symbolism. Journal of Interactive Marketing, 33, 27-42, CrossRef

- $\quad$ Brady, M. K., Cronin, J. J., Fox, G. L., \& Roehm, M. L. (2008). Strategies to offset performance failures: The role of brand equity. Journal of Retailing, 84(2), 151-164, CrossRef

- $\quad$ Broady-Preston, J., Tedd, L., Kate Merry, S., \& Simon, A. (2012). Living and lurking on LiveJournal: The benefits of active and non-active membership. Paper presented at the Aslib Proceedings.

- Casaló, L., Flavián, C., \& Guinalíu, M. (2007). The impact of participation in virtual brand communities on consumer trust and loyalty: The case of free software. Online Information Review, 31(6), 775-792. doi: doi:10.1108/14684520710841766, CrossRef

- Chandon, P., Wansink, B., \& Laurent, G. (2000). A benefit congruency framework of sales promotion effectiveness. Journal of marketing, 64(4), 65-81, CrossRef

- Chaudhuri, A., \& Holbrook, M. B. (2002). Product-class effects on brand commitment and brand outcomes: The role of brand trust and brand affect. The Journal of Brand Management, 10(1), 33-58, CrossRef

- Chen, H., Papazafeiropoulou, A., Chen, T.-K., Duan, Y., \& Liu, H.-W. (2014). Exploring the commercial value of social networks: Enhancing consumers' brand experience through Facebook pages. Journal of Enterprise Information Management, 27(5), 576-598, CrossRef

- De Chernatony, L., \& Riley, F. D. O. (1999). Experts' views about defining services brands and the principles of services branding. Journal of Business Research, 46(2), 181-192, CrossRef

- Delgado-Ballester, E., \& Munuera-Alemán, J. L. (2005). Does brand trust matter to brand equity? Journal of Product \& Brand Management, 14(3), 187-196. doi: doi:10.1108/10610420510601058, CrossRef

- Dholakia, U. M., Bagozzi, R. P., \& Pearo, L. K. (2004). A social influence model of consumer participation in network- and small-group-based virtual communities. International Journal of Research in Marketing, 21(3), 241-263, CrossRef

- Dholakia, U. M., \& Vianello, S. (2009). Effective brand community management: Lessons from customer enthusiasts. Available at SSRN 1512090, $\underline{\text { CrossRef }}$

- Duffett, R. G. (2015). Facebook advertising's influence on intention-to-purchase and purchase amongst Millennials. Internet Research, 25(4), 498-526. doi: 10.1108/IntR-01-2014-0020, CrossRef

- Flavián, C., \& Guinalíu, M. (2005). The influence of virtual communities on distribution strategies in the internet. International Journal of Retail \& Distribution Management, 33(6), 405-425. doi: doi:10.1108/09590550510600843, CrossRef

- Garretson, R. (2008). Future tense: The global CMO. accessed September 2014 at http://graphics. eiu. com/upload. Google\% 20Text. pdf.

- Gilbert, D., \& Jackaria, N. (2002). The efficacy of sales promotions in UK supermarkets: a consumer view. International Journal of Retail \& Distribution Management, 30(6), 315-322, CrossRef

- Goodman, L. A. (1961). Snowball sampling. The annals of mathematical statistics, 148-170, CrossRef

- Gummerus, J., Liljander, V., Weman, E., \& Pihlström, M. (2012). Customer engagement in a Facebook brand community. Management Research Review, 35(9), 857-877. doi: doi:10.1108/01409171211256578, CrossRef 
- Habibi, M. R., Laroche, M., \& Richard, M.-O. (2014). The roles of brand community and community engagement in building brand trust on social media. Computers in Human Behavior, 37, 152-161, CrossRef

- Hayes, A. F. (2012). PROCESS: A versatile computational tool for observed variable mediation, moderation, and conditional process modeling.

- Hennig-Thurau, T., Gwinner, K. P., Walsh, G., \& Gremler, D. D. (2004). Electronic word-of-mouth via consumer-opinion platforms: What motivates consumers to articulate themselves on the Internet? Journal of Interactive Marketing, 18(1), 38-52, CrossRef

- Ho, C.-W. (2014). Consumer behavior on Facebook: does consumer participation bring positive consumer evaluation of the brand? EuroMed Journal of Business, 9(3), 252-267, CrossRef

- Hung, H.-Y., \& Lin, T.-L. (2015). A moderated mediation model of consumers' role behaviors in brand communities. Asia Pacific Management Review, 20(3), 191-200, CrossRef

- Hur, W.-M., Ahn, K.-H., \& Kim, M. (2011). Building brand loyalty through managing brand community commitment. Management Decision, 49(7), 1194-1213, CrossRef

- Kabadayi, S., \& Price, K. (2014). Consumer - brand engagement on Facebook: liking and commenting behaviors. Journal of Research in Interactive Marketing, 8(3), 203-223. doi: doi:10.1108/JRIM-12-2013-0081, CrossRef

- $\quad$ Kang, J., Tang, L., \& Fiore, A. M. (2015). Restaurant brand pages on Facebook: Do active member participation and monetary sales promotions matter? International Journal of Contemporary Hospitality Management, 27(7), 1662-1684. doi: doi:10.1108/IJCHM-02-2014-0075, CrossRef

- Keller, K. L. (2001). Building customer-based brand equity: A blueprint for creating strong brands.

- Keller, K. L. (2013). Strategic Brand Management (S. Wall Ed. 4 Edition ed.): Pearson Education, Inc.

- Kim, H. b., Kim, W. G., \& An, J. A. (2003). The effect of consumer-based brand equity on firms' financial performance. Journal of Consumer Marketing, 20(4), 335-351. doi: doi:10.1108/07363760310483694, CrossRef

- Kim, Y. H., Kim, D. J., \& Wachter, K. (2013). A study of mobile user engagement (MoEN): Engagement motivations, perceived value, satisfaction, and continued engagement intention. Decision Support Systems, 56, 361-370, CrossRef

- Kucukemiroglu, S., \& Kara, A. (2015). Online word-of-mouth communication on social networking sites: An empirical study of Facebook users. International Journal of Commerce and Management, 25(1), 2-20, CrossRef

- Lee, Y.-K., Ahn, W.-K., \& Kim, K. (2008). A study on the moderating role of alternative attractiveness in the relationship between relational benefits and customer loyalty. International Journal of hospitality \& tourism administration, 9(1), 52-70, $\underline{\text { CrossRef }}$

- Lembke, S., \& Wilson, M. G. (1998). Putting the" team" into teamwork: Alternative theoretical contributions for contemporary management practice. Human Relations, 51(7), 927-944, CrossRef

- Li, N., Robson, A., \& Coates, N. (2014). Luxury brand commitment: a study of Chinese consumers. Marketing Intelligence \& Planning, 32(7), 769-793, $\underline{\text { CrossRef }}$

- Lin, Y.-T. J., Lin, M.-Y. T., \& Li, K.-C. (2015). Consumer involvement model of fan page: Mining from Facebook data of a real celebrity fashion brand. Paper presented at the 2015 12th International Conference on Service Systems and Service Management (ICSSSM).

- $\quad$ Luarn, P., Lin, Y.-F., \& Chiu, Y.-P. (2015). Influence of Facebook brand-page posts on online engagement. Online Information Review, 39(4), 505-519. doi: doi:10.1108/OIR-01-2015-0029, CrossRef

- Malik, A., Hiekkanen, K., Dhir, A., \& Nieminen, M. (2016). Impact of privacy, trust and user activity on intentions to share Facebook photos. Journal of Information, Communication and Ethics in Society, 14(4), 364382. doi: doi:10.1108/JICES-06-2015-0022, CrossRef

- Mathwick, C., Malhotra, N., \& Rigdon, E. (2001). Experiential value: conceptualization, measurement and application in the catalog and Internet shopping environment 2 . Journal of Retailing, 77(1), 39-56, CrossRef

- McAlexander, J. H., Schouten, J. W., \& Koenig, H. F. (2002). Building brand community. Journal of marketing, 66(1), 38-54, $\underline{\text { CrossRef }}$

- McKenna, K. Y., \& Bargh, J. A. (1999). Causes and consequences of social interaction on the Internet: A conceptual framework. Media Psychology, 1(3), 249-269, $\underline{\text { CrossRef }}$

- Muniz, A. M., \& O'guinn, T. C. (2001). Brand community. Journal of consumer research, 27(4), 412-432, $\underline{\text { CrossRef }}$ 
- $\quad$ Munnukka, J., Karjaluoto, H., \& Tikkanen, A. (2015). Are Facebook brand community members truly loyal to the brand? Computers in Human Behavior, 51, 429-439, CrossRef

- Nishimura, S., Waryszak, R., \& King, B. (2006). Guidebook use by Japanese tourists: a qualitative study of Australia inbound travellers. International Journal of Tourism Research, 8(1), 13-26, CrossRef

- Nonnecke, B., Andrews, D., \& Preece, J. (2006). Non-public and public online community participation: Needs, attitudes and behavior. Electronic Commerce Research, 6(1), 7-20, $\underline{\text { CrossRef }}$

- Noyan, F., \& Şimşek, G. G. (2014). The Antecedents of Customer Loyalty. Procedia - Social and Behavioral Sciences, 109(0), 1220-1224, CrossRef

- Ouwersloot, H., \& Odekerken-Schröder, G. (2008). Who's who in brand communities - and why? European Journal of Marketing, 42(5/6), 571-585. doi: doi:10.1108/03090560810862516, CrossRef

- Papacharissi, Z., \& Rubin, A. M. (2000). Predictors of Internet use. Journal of broadcasting \& electronic media, 44(2), 175-196, CrossRef

- $\quad$ Pappu, R., \& Quester, P. G. (2016). How does brand innovativeness affect brand loyalty? European Journal of Marketing, 50(1/2), 2-28. doi: doi:10.1108/EJM-01-2014-0020, CrossRef

- Parola, F., Satta, G., Penco, L., \& Persico, L. (2014). Destination satisfaction and cruiser behaviour: The moderating effect of excursion package. Research in Transportation Business \& Management, 13(0), 53-64, CrossRef

- $\quad$ Parsa, A., Eidelou, P. H., Abdolahi, S., Maleki, M., \& Mehrabi, S. (2013). INTERDISCIPLINARY JOURNAL OF CONTEMPORARY RESEARCH IN BUSINESS.

- Pihlstrom, J. G. V. L. E. W. M. (2012). Customer engagment in a Facebook brand community. Management Research Review, 45(9), 857-877.

- $\quad$ Rajah, E., Marshall, R., \& Nam, I. (2008). Relationship glue: customers and marketers co-creating a purchase experience. NA-Advances in Consumer Research Volume 35.

- $\quad$ Rios, R. E., \& Riquelme, H. E. (2008). Brand equity for online companies. Marketing Intelligence \& Planning, 26(7), 719-742. doi: doi:10.1108/02634500810916681, $\underline{\text { CrossRef }}$

- Royo-Vela, M., \& Casamassima, P. (2011). The influence of belonging to virtual brand communities on consumers' affective commitment, satisfaction and word-of-mouth advertising: The ZARA case. Online Information Review, 35(4), 517-542. doi: doi:10.1108/14684521111161918, CrossRef

- Shabbir, R. (2015). Understanding Digital Marketing Based on Online Brand Communities: Leveraging Value Creation and Community Commitment. (Doctoral Degree), Huazhong University of Science and Technology, Unpublished.

- Shang, R.-A., Chen, Y.-C., \& Liao, H.-J. (2006). The value of participation in virtual consumer communities on brand loyalty. Internet Research, 16(4), 398-418, CrossRef

- Shi, S., Chen, Y., \& Chow, W. S. (2016). Key values driving continued interaction on brand pages in social media: An examination across genders. Computers in Human Behavior, 62, 578-589, CrossRef

- Sotheara, H., Jing, Z., \& Yat, Y. (2016). Leveraging Brand Loyalty in Service Branding: The Role of Satisfaction. Journal of International Business Research and Marketing, 1(6), 17-23, CrossRef

- Sweeney, J., \& Swait, J. (2008). The effects of brand credibility on customer loyalty. Journal of Retailing and Consumer Services, 15(3), 179-193, $\underline{\text { CrossRef }}$

- Thompson, S. A., \& Sinha, R. K. (2008). Brand Communities and New Product Adoption: The Influence and Limits of Oppositional Loyalty. Journal of marketing, 72(6), 65-80, CrossRef

- Treadaway, C., \& Smith, M. (2012). Facebook marketing: An hour a day: John Wiley \& Sons.

- Wimmer, R., \& Dominick, J. (2013). Mass media research: Cengage learning.

- Wood, L. (2000). Brands and brand equity: definition and management. Management Decision, 38(9), 662-669. doi: doi:10.1108/00251740010379100, $\underline{\text { CrossRef }}$

- Xiang, Z., Magnini, V. P., \& Fesenmaier, D. R. (2015). Information technology and consumer behavior in travel and tourism: Insights from travel planning using the internet. Journal of Retailing and Consumer Services, 22(0), 244-249, $\underline{\text { CrossRef }}$

- $\quad$ Xu, C., Ryan, S., Prybutok, V., \& Wen, C. (2012). It is not for fun: An examination of social network site usage. Information \& Management, 49(5), 210-217, CrossRef

- Yang, H.-L., \& Lin, C.-L. (2014). Why do people stick to Facebook web site? A value theory-based view. Information Technology \& People, 27(1), 21-37, CrossRef 
- Yang, T. (2012). The decision behavior of Facebook users. Journal of Computer Information Systems, 52(3), 50-59.

- Zhang Jing, H. S., Mom Virak. (2017). Examining virtual brand community on Facebook brand page. Unpublished paper.

- Zhao, X., \& Lynch Jr, G. (2010). John, Chen, Qimei. Reconsidering Baron and Kenny: myths and truths about mediation analysis, J. Consum. Res, 37(2), 197-206, CrossRef 